(c) 2017, THE AUTHORS. Published by FASS and Elsevier Inc. on behalf of the American Dairy Science Association ${ }^{\circledR}$.

This is an open access article under the CC BY-NC-ND license (http://creativecommons.org/licenses/by-nc-nd/3.0/).

\title{
Ratio of dietary rumen degradable protein to rumen undegradable protein affects nitrogen partitioning but does not affect the bovine milk proteome produced by mid-lactation Holstein dairy cows
}

\author{
R. Tacoma, ${ }^{*}$ J. Fields, † D. B. Ebenstein, ${ }^{*}$ Y.-W. Lam,†‡ and S. L. Greenwood*1 \\ *Department of Animal and Veterinary Sciences, \\ †Vermont Genetics Network Proteomics Facility, and \\ ‡Department of Biology, University of Vermont, Burlington, 05405
}

\begin{abstract}
Little is known about the bovine milk proteome or whether it can be affected by diet. The objective of this study was to determine if the dietary rumen degradable protein (RDP):rumen undegradable protein (RUP) ratio could alter the bovine milk proteome. Six Holstein cows (parity: $2.5 \pm 0.8$ ) in mid lactation were blocked by days in milk ( $80 \pm 43 \mathrm{~d}$ in milk) and milk yield ( 57.5 $\pm 6.0 \mathrm{~kg}$ ) and randomly assigned to treatment groups. The experiment was conducted as a double-crossover design consisting of three 21-d periods. Within each period, treatment groups received diets with either (1) a high RDP:RUP ratio (RDP treatment: $62.4: 37.6 \%$ of crude protein) or (2) a low RDP:RUP ratio (RUP treatment: $51.3: 48.7 \%$ of crude protein). Both diets were isonitrogenous and isoenergetic (crude protein: 18.5\%, net energy for lactation: $1.8 \mathrm{Mcal} / \mathrm{kg}$ of dry matter). To confirm $\mathrm{N}$ and energy status of cows, dry matter intake was determined daily, rumen fluid samples were collected for volatile fatty acid analysis, blood samples were collected for plasma glucose, $\beta$-hydroxybutyrate, urea nitrogen, and fatty acid analysis, and total 24-h urine and fecal samples were collected for $\mathrm{N}$ analysis. Milk samples were collected to determine the general milk composition and the protein profile. Milk samples collected for high-abundance protein analysis were subjected to HPLC analysis to determine the content of $\alpha$-casein, $\beta$-casein, and $\kappa$-casein, as well as $\alpha$-lactalbumin and $\beta$-lactoglobulin. Samples collected for low-abundance protein analysis were fractionated, enriched using ProteoMiner treatment, and separated using sodium dodecyl sulfate-PAGE. After excision and digestion, the peptides were analyzed using liquid chromatography (LC) tandem mass spectrometry (MS/MS). The LC-MS/MS data were analyzed using PROC GLIMMIX of SAS (version 9.4, SAS Institute
\end{abstract}

Received January 26, 2017.

Accepted May 17, 2017.

${ }^{1}$ Corresponding author: Sabrina.Greenwood@uvm.edu
Inc., Cary, NC) and adjusted using the MULTTEST procedure. All other parameters were analyzed using PROC MIXED of SAS. No treatment differences were observed in dry matter intake, milk yield, general milk composition, plasma parameters, or rumen volatile fatty acid concentrations, indicating no shift in total energy or protein available. Milk urea $\mathrm{N}$ and plasma urea $\mathrm{N}$ concentrations were higher in the RDP group, indicating some shift in $\mathrm{N}$ partitioning due to diet. A total of 595 milk proteins were identified, with $83 \%$ of these proteins known to be involved in cellular processes. Although none of the low-abundance proteins identified by LC-MS/MS were affected by diet, feeding a diet high in RUP decreased $\beta$-casein, $\kappa$-casein, and total milk casein concentration. Further investigations of the interactions between diet and the milk protein profile are needed to manipulate the milk proteome using diet.

Key words: milk protein, proteomics, bioactive, lowabundance protein

\section{INTRODUCTION}

It is well established that milk plays an important role in neonatal nutrition; however, research investigating the concept that milk proteins are a source of bioactive compounds that have physiological importance beyond AA provision is relatively sparse. Many of the identified bioactive peptides are released after cleavage of the high-abundance milk protein fraction, which include all casein isoforms, as well as whey proteins $\alpha$-LA and $\beta$-LG. Identified low-abundance milk proteins, which include all other whey proteins, are known to have functionality as either cleaved peptide fragments or as entire intact proteins that can withstand gastric cleavage. These bioactive proteins and peptides, derived from both the low- and high-abundance protein fraction, have been identified to have a large breadth of activity and play a role in human health, modulating physiological functions by various binding interactions with target cells and organs inducing beneficial 
physiological responses. Various functional properties associated with bioactive proteins and peptides include antimicrobial, antihypertensive, opioid, immunomodulatory, mineral binding, and antioxidative activities (Korhonen and Pihlanto, 2006; Sharma et al., 2011; Park and Nam, 2015). Investigation of human breast milk has identified several bioactive proteins and peptides that can influence infant health, particularly gut physiology and motility (Chatterton et al., 2013). Milk proteins present in bovine milk have also been identified to have bioactivity and cross-reactivity with human cells (Buccigrossi et al., 2007; Lönnerdal et al., 2011; Raikos and Dassios, 2014). Understanding secretion profiles of bovine milk proteins as well as mechanisms to manipulate this protein profile are important steps in further enhancing the healthfulness of bovine milk products.

The profile of proteins in bovine milk is influenced by animal factors such as breed, mastitis, and stage of lactation (Boehmer et al., 2010b; Zhang et al., 2015a; Tacoma et al., 2016). The mechanisms that affect the milk proteome at the cellular level within the mammary could be a result of AA supply or energy status on the transcriptional or translational efficiencies or rates within the cell (Osorio et al., 2016), or a result of posttranslational regulation such as changes in protein folding or intracellular protein transport (Ghazalpour et al., 2011). However, extracellular protein shifts may play just as important a role in determining the makeup of the milk proteome. Gene ontology (GO) analysis of the low-abundance bovine milk proteome fractions has consistently demonstrated that the majority of the identified proteins are extracellular in origin (Tacoma et al., 2016; Wang et al., 2017), suggesting that not only cell-specific regulation within the mammary gland as outlined above could affect the milk proteome, but that nonsecretory cell specific metabolic changes could also lead to shifts in the milk proteome via junction leakage, or para- or trans-cellular passage of proteins.

Altering the milk protein profile and bioactive properties of the milk by manipulating the diet of the dairy cow offers a promising approach to naturally enhance the healthfulness of milk products. Research examining the relationship between nutrition and the bovine milk protein profile is limited and nutrition is a significant management factor that has the potential to alter milk protein composition (Kennelly et al., 2005; Tripathi, 2014). Christian et al. (1999) altered the proportions of high abundance bovine milk proteins by feeding a lupin-wheat-based diet, a high RUP source, to lactating dairy cows compared with cows fed spring-pasture, a high RDP source. Cows offered the lupin-wheat-based diet had higher concentrations of $\alpha_{\mathrm{S}_{1}-} \mathrm{CN}, \alpha_{\mathrm{S}^{2}} \mathrm{CN}$, and $\gamma-\mathrm{CN}$ in the milk compared with cows on the high pas- ture diet, whereas concentrations of $\beta-\mathrm{CN}$ and $\kappa-\mathrm{CN}$ were present at higher concentrations in milk from cows fed spring pasture compared with cows on the lupin-based diet. More recently, a study was published outlining changes in high abundance milk protein expression patterns in response to inclusion of different corn and soybean feedstuffs in the ration. Although the type of corn included in the diet did not influence the milk protein profile, inclusion of heat-treated soybean meal resulted in a decrease in $\beta-\mathrm{CN}$ and zinc- $\alpha-2$ glycoprotein fragments indicating the availability of RDP to influence secretion of specific milk proteins. These authors also reported differential expression of $\alpha$-LA and zinc- $\alpha$-2-glycoprotein due to diet, suggesting that ruminal microbial protein synthesis could affect the milk protein profile ( $\mathrm{Li}$ et al., 2015). Mechanistically, shifts in the MCP versus diet-derived digestible RUP fractions reaching the small intestine are known to alter postabsorptive $\mathrm{N}$ metabolism, particularly affecting intestinal, hepatic, renal, and muscular metabolism (Hristov et al., 2004; Reynal and Broderick, 2005; Brito and Broderick, 2007), and would alter the blood proteome and $\mathrm{N}$ available for uptake and use for mammary protein synthesis but also the profile of nonmammary derived extracellular proteins within the milk via the mechanisms described above. Upon closer investigation of diets used in the research outlined by Christian et al. (1999) and $\mathrm{Li}$ et al. (2015), it is clear that they include diets with different RDP:RUP ratios; however, other nutrient differences between diets have made the interpretation of the effect of dietary protein content on the milk proteome difficult.

We hypothesize that it is the difference in diet RDP:RUP protein fraction that ultimately leads to a change in the bovine milk proteome. The goal of our study was to create 2 isonitrogenous and isoenergetic dairy rations with at least a $10 \%$ difference in the RDP:RUP ratio and examine the bovine milk proteome in milk samples collected from cows consuming these different diets.

\section{MATERIALS AND METHODS}

\section{Experimental Design}

Six mid-lactation Holstein dairy cows (parity: $2.5 \pm$ 0.8 ) were blocked by DIM ( $80 \pm 43$ DIM) and milk yield $(57.5 \pm 6.0 \mathrm{~kg})$ and then were randomly divided into 2 experimental groups in a double-crossover design. Each of the 3 periods lasted $21 \mathrm{~d}$ and consisted of $16 \mathrm{~d}$ for diet adaptation and the last $5 \mathrm{~d}$ for sample collection. Cows were maintained in the same tie-stall facility with sawdust bedding at the Paul R. Miller Research and Educational Center (University of Vermont, 
Burlington). All animal procedures were approved by the Institutional Animal Care and Use Committee at the University of Vermont.

\section{Diet and Feeding}

All animals had free access to water throughout the trial and were fed to target $10 \%$ refusals. Cows were fed the same partial mixed ration once daily $(0600 \mathrm{~h})$ and a pelleted top-dress that was mixed thoroughly into the ration thrice daily $(0330,1100$, and $1800 \mathrm{~h})$ that was formulated to contain either (1) a higher RDP:RUP ratio (RDP diet), or (2) a high RUP:RDP ratio (RUP diet). The treatment groups switched between the RDP or RUP topdress after each period. Diets were formulated to be isonitrogenous and isoenergetic, and included urea, soybean meal, canola meal, and commercially available bypass AA sources to create the different RDP:RUP ratio (see Table 1 for nutrient profile and complete formulation). Feed samples were collected thrice weekly and stored at $-20^{\circ} \mathrm{C}$. Feed samples were later composited within feedstuff over each period throughout the experiment and analyzed by wet chemistry (DairyOne, Ithaca, NY). Daily feed refusals from each animal were collected and weighed each morning before feeding for the duration of the trial. A subsample of these refusals were stored at $-20^{\circ} \mathrm{C}$ until analysis and subsequently dried at $65^{\circ} \mathrm{C}$ for $48 \mathrm{~h}$ to calculate individual daily DMI.

\section{Milk Production and Milk Sample Collection}

Cows were milked twice daily (0700 and $1600 \mathrm{~h}$ ). Milk yield was recorded daily and milk samples were collected on d 0 as baseline samples and on d 16 to 19 at the end of each experimental period from the morning and afternoon milking. One set of milk subsamples were collected and preserved with bronopol and natamycin (Broad Spectrum Microtabs, D \& F Control Systems Inc., Dublin, CA) and stored at $4^{\circ} \mathrm{C}$. Samples were analyzed commercially (DHIA, Lancaster, PA) within $3 \mathrm{~d}$ after collection for general milk composition. A second set of milk subsamples collected for analysis of high abundance proteins were immediately put on ice and skimmed within $2 \mathrm{~h}$ of collection at $4,000 \times g$ for $10 \mathrm{~min}$ at $4^{\circ} \mathrm{C}$. The fat layer was removed and the skim milk samples were stored at $-20^{\circ} \mathrm{C}$ until further analysis. A third set of milk subsamples collected for low abundance protein analysis were immediately frozen in a dry-ice ethanol bath after collection and stored at $-80^{\circ} \mathrm{C}$. Milk samples collected for high abundance protein analysis were analyzed individually, whereas milk samples collected for low abundance protein analysis were composited during the last week of each period by individual animal based on milk weights recorded at each milking.

\section{Blood Collection}

Blood samples were collected from the tailhead of each cow into heparinized and EDTA-coated tubes (Becton Dickinson and Company, Franklin Lakes, NJ) after milking (0800 and $1900 \mathrm{~h}$ ) on d 0, and again on d 17, 19, and 21 of each period. Samples were placed on ice immediately after collection and plasma was isolated within $2 \mathrm{~h}$ of blood collection by centrifugation at $3,000 \times g$ for $15 \mathrm{~min}$ at $4^{\circ} \mathrm{C}$. Plasma was transferred into polypropylene tubes and frozen at $-20^{\circ} \mathrm{C}$ until analysis. Plasma samples were later thawed and aliquoted into $0.5-\mathrm{mL}$ centrifuge tubes and plasma concentrations of BHB (Sigma, St. Louis, MO), plasma urea nitrogen (PUN; Teco Diagnostics, Anaheim, CA), glucose (Sigma), and fatty acids (ZenBio Inc., Research Triangle Park, NC) were determined using commercially available kits. Samples were analyzed according to the manufacturer's instructions and all coefficients of variation were $<5 \%$.

\section{Rumen Fluid Collection}

Rumen fluid samples were collected by esophageal intubation, which was performed at $1300 \mathrm{~h}$ on $\mathrm{d} 0$, and again on d 19 and 21 of each period to determine rumen

Table 1. Ingredient and nutrient composition of the diets ${ }^{1}$

\begin{tabular}{lcc}
\hline & \multicolumn{2}{c}{ Treatment } \\
\cline { 2 - 3 } Item & RDP & RUP \\
\hline Ingredient (\% of DM) & & \\
Corn silage & 48.5 & 48.5 \\
Haylage & 6.4 & 6.4 \\
Soybean meal & 13.1 & 5.6 \\
Molasses cane & 1.4 & 1.1 \\
Corn grain & 14.2 & 14.0 \\
Citrus pulp dry & 1.1 & 1.2 \\
Canola meal & 3.6 & - \\
Wheat middlings & 0.7 & - \\
Wheat red dog & 1.4 & - \\
Berga fat & 0.9 & - \\
Corn distillers & - & 3.5 \\
Vitamins/minerals & 2.9 & 2.7 \\
Amino max & 4.8 & 13.9 \\
Urea & 0.4 & 0.14 \\
Amino enhancer & - & 1.4 \\
Nutrient composition (\% of DM) & & \\
DM (\%) & 57.1 & 57.0 \\
CP & 18.5 & 18.5 \\
RDP & 11.7 & 9.0 \\
RUP & 6.8 & 9.5 \\
ADF & 20.3 & 21.7 \\
NDF & 30.8 & 32.7 \\
NFC & 40.1 & 39.1 \\
NE (Mcal/kg) & 1.8 & 1.8 \\
\hline Stppr of fed: Poun & &
\end{tabular}

${ }^{1}$ Supplier of feed: Poulin Grain (Newport, VT). 
VFA profiles and verify that no major shifts in rumen energetics occurred as a result of treatment. Rumen fluid samples were centrifuged at 14,000 $\times g$ for 20 min at $8^{\circ} \mathrm{C}$ and the supernatant was filtered through a 25-mm hardened ashless filter (Whatman 540). The extracted supernatant was mixed with equal parts of an internal standard $(50 \mu \mathrm{mol} / \mathrm{mL}$ of trimethyl acetic acid in $0.06 M$ oxalic acid). The samples were analyzed as per methods similar to those previously described by Dann et al. (2008). Nitrogen was used as the carrier gas at a flow rate of $15 \mathrm{~mL} / \mathrm{min}$, where the other gases were purified air at $300 \mathrm{~mL} / \mathrm{min}$ and hydrogen gas at $30 \mathrm{~mL} / \mathrm{min}$ to the flame ionization detector. The oven temperature was held at $175^{\circ} \mathrm{C}$ for $25 \mathrm{~min}$ and the injector and detector temperature were held at $200^{\circ} \mathrm{C}$. Star Chromatography software (v. 6, Agilent Technologies, Santa Clara, CA) was used to analyze peaks based on the flame ionization detector response. Peaks were identified using individual VFA standards (Supelco, Sigma-Aldrich, St. Louis, MO) and molar proportions were calculated using molecular weights and sample volume.

\section{Urine and Fecal Collection}

Urine and fecal samples were collected for $24 \mathrm{~h}$ on $\mathrm{d}$ 0 and again on d 19 of each period to assess changes in $\mathrm{N}$ partitioning as a result of diet treatment. Urine and feces was collected using buckets and weights of each event were recorded before the sample was thoroughly mixed and a subsample collected. Four drops of sulfuric acid was added immediately to each urine subsample to acidify the sample to a $\mathrm{pH}<4$. Fecal and acidified urine subsamples were placed on ice after collection and stored at $-20^{\circ} \mathrm{C}$ until further analysis. All urine and fecal samples were thawed overnight at $4^{\circ} \mathrm{C}$, and composited within animal based on the volume of each event in proportion to their total daily urine and fecal weights. The composite fecal samples were dried for 48 $\mathrm{h}$ at $65^{\circ} \mathrm{C}$ and ground. Composite urine and dried fecal samples were then submitted for $\mathrm{N}$ analysis to a commercial laboratory (University of Vermont Agricultural and Environmental Testing Laboratory, University of Vermont, Burlington). The estimated $\mathrm{N}$ balance of each cow was determined through the following calculation: $\mathrm{N}$ retained $=\mathrm{N}$ content of feed $(\mathrm{g} / \mathrm{d} ; \mathrm{g}$ of $\mathrm{CP}$ intake/d/6.25) - [urine $\mathrm{N}$ output $(\mathrm{g} / \mathrm{d})+$ fecal $\mathrm{N}$ output $(\mathrm{g} / \mathrm{d})+$ milk $\mathrm{N}$ output $(\mathrm{g} / \mathrm{d})]$. The milk $\mathrm{N}$ content was assumed to be milk protein/6.38.

\section{Analysis of the High Abundance Milk Proteins}

The skim milk samples stored for high abundance milk protein determination were thawed at $4^{\circ} \mathrm{C}$ over- night and mixed thoroughly by vortexing and then sonication at $33 \mathrm{~W}$ for $15 \mathrm{~min}$ at less than $25^{\circ} \mathrm{C}$, cooled in an ice bath (Bransonic Model 220, Branson Ultrasonics, Danbury, CT). Following sonication, a $0.5-\mathrm{mL}$ aliquot of milk was pipetted into a borosilicate test tube. An equal amount of reducing buffer (6.0 $M$ guanidine hydrochloride, $5.0 \mathrm{~m} M$ trisodium citrate dehydrate, $20.0 \mathrm{~m} M$ dithiothreitol) was then added to the sample before incubation at room temperature for $1 \mathrm{~h}$. The milk/buffer mixture was allowed to react for at least $1 \mathrm{~h}$ at room temperature, a further weighed volume of the buffer without the dithiothreitol reducing agent was added, and the sample transferred to a syringe and passed through a $0.45-\mu \mathrm{m}$ regenerated cellulose membrane syringe filter (Sartorius, Goettingen, Germany) into an HPLC autosampler vial.

Samples were analyzed using a Shimadzu (Kyoto, Japan) HPLC with the following solvent gradient protocol, outlined by Bordin et al. (2001) with minor modifications: linear gradient from 26.5 to $28 \%$ eluent $\mathrm{B}$ in $2.5 \mathrm{~min}(0.60 \% \mathrm{~B} / \mathrm{min})$, an isocratic elution at $28.0 \% \mathrm{~B}$ for 4 min then from 28.6 to $30.6 \% \mathrm{~B}$ in $3.4 \mathrm{~min}$ $(0.70 \% \mathrm{~B} / \mathrm{min})$, and from 30.6 to $33.5 \% \mathrm{~B}$ in $2.9 \mathrm{~min}$ $(1.0 \% \mathrm{~B} / \mathrm{min})$, followed by an isocratic elution at $33.5 \%$ $\mathrm{B}$ for $3 \mathrm{~min}$, an increase from 33.5 to $36.1 \% \mathrm{~B}$ in 2.6 $\min (1.0 \% \mathrm{~B} / \mathrm{min})$, an isocratic elution at $36.1 \% \mathrm{~B}$ for 5 min, an increase from 36.1 to $37 \%$ B in $1.5 \mathrm{~min}(0.6 \%$ $\mathrm{B} / \mathrm{min}$ ), an isocratic elution at $37 \% \mathrm{~B}$ for $2 \mathrm{~min}$, and a final increase to $41 \% \mathrm{~B}$ in $6.5 \mathrm{~min}(0.60 \% \mathrm{~B} / \mathrm{min})$, for a total run time of $42 \mathrm{~min}$ at a flow rate of $0.50 \mathrm{~mL} / \mathrm{min}$.

For each analysis, $4 \mu \mathrm{L}$ of sample was injected into the HPLC. Chromatograms were obtained at $214 \mathrm{~nm}$ and individual protein peaks were identified by comparison to injections of standard protein solutions prepared in our laboratory from purchased isolated proteins (Sigma), and integrated using Shimadzu LCsolution software (version 1.22, 2006) to determine the area under the peak. For quantification of total $\alpha-\mathrm{CN}$, as well as $\beta-\mathrm{CN}, \kappa-\mathrm{CN}, \alpha-\mathrm{LA}$, and $\beta-\mathrm{LG}$, standard curves were directly determined by injecting known concentrations of the standard protein solutions. The constituent $\alpha_{\mathrm{S}_{1}} \mathrm{CN}$ and $\alpha_{\mathrm{S}_{2}} \mathrm{CN}$ proteins are not readily available as isolates; therefore, quantification of $\alpha_{\mathrm{S} 1}-\mathrm{CN}$ and $\alpha_{\mathrm{S}_{2}} \mathrm{CN}$ was performed by interpolating the results from the total $\alpha-\mathrm{CN}$ standard curve for semiquantitative comparisons between experimental groups.

\section{Low Abundance Protein Isolation, Digestion, and Identification}

Milk samples collected for low abundance protein analysis were thawed overnight at $4^{\circ} \mathrm{C}$. To obtain a representative sample, milk samples from the morning and afternoon milking were composited within cow 
from d 16 to 19 within each period according to milk weights at each milking. The resulting $50-\mathrm{mL}$ composite samples were subjected to fractionation and proteomic techniques as previously described (Tacoma et al., 2016). Briefly, protease inhibitor cocktail (Sigma) was added $(0.24 \mathrm{~mL} / \mathrm{g}$ of protein) to each composite sample. Samples were then centrifuged at $4,000 \times g$ for 15 min at $4^{\circ} \mathrm{C}$, and the skim milk samples were then combined with $60 \mathrm{mM} \mathrm{CaCl}$ and adjusted to a $\mathrm{pH}$ of 4.3 using 30\% acetic acid solution (Fisher Scientific, Fair Lawn, NJ). The whey-containing supernatant was collected after centrifugation of samples at 189,000 $\times g$ at $4^{\circ} \mathrm{C}$ for $70 \mathrm{~min}$, and subsequently stored at $-80^{\circ} \mathrm{C}$. Samples were lyophilized, reconstituted in PBS, and the protein content of each sample was determined using the bicinchoninic acid assay kit (Pierce, Rockford, IL) using BSA as the standard. The low-abundance protein fraction was enriched using a ProteoMiner kit (BioRad, Hercules, CA) and proteins were eluted in $20 \mu \mathrm{L}$ of $4 \times$ Laemmli sample buffer (8\% SDS, $40 \%$ glycerol, $250 \mathrm{~m} M$ Tris $\mathrm{pH}$ 6.8, $400 \mathrm{~m} M$ dithiothreitol with trace amounts of bromophenol blue) after heating the samples to $95^{\circ} \mathrm{C}$ for $10 \mathrm{~min}$. The eluted samples were then separated by SDS-PAGE in precast 8 to $16 \%$ polyacrylamide gels (BioRad) using Tris-glycine $(\mathrm{pH}$ 8.3 ) containing $0.1 \%$ SDS as the running buffer. Gels were stained by incubating in Coomassie Brilliant Blue (BioRad) overnight, and destaining was performed using a solution of $10 \%$ acetic acid, $40 \%$ methanol, and $50 \%$ water. The Gel Doc XR + system (BioRad) was used to scan gels before gel excision. Each sample was cut into 15 segments, cut into $1 \mathrm{~mm}$ cubes, destained with $50 \mathrm{~m} M$ ammonium bicarbonate in $50 \%$ acetonitrile, and reduced by $10 \mathrm{~m} M$ dithiothreitol at $55^{\circ} \mathrm{C}$ for $1 \mathrm{~h}$. Samples were then alkylated with $55 \mathrm{mM}$ iodoacetamide in the dark at room temperature for 45 min before being washed and dehydrated twice with $100 \mathrm{~m} M$ ammonium bicarbonate and $100 \%$ acetonitrile. The gel segments were dried in a SpeedVac (Scientific Support, Hayward, CA) and digested by reaction with $7 \mu \mathrm{g} / \mu \mathrm{L}$ of trypsin for $18 \mathrm{~h}$ at $37^{\circ} \mathrm{C}$. The digestion was ceased using $50 \mathrm{uL}$ of $5 \%$ formic acid, and the resulting peptide solution was dried in a SpeedVac (Scientific Support). Samples were resuspended in $10 \mu \mathrm{L}$ of a solution containing $2.5 \%$ acetonitrile and $2.5 \%$ formic acid for liquid chromatography (LC)-MS/MS analysis.

Samples were analyzed by LC-MS/MS on a LTQ MS (Thermo Fisher Scientific, Waltham, MA), and $5 \mu \mathrm{L}$ of the digest was loaded onto a $100 \mu \mathrm{m} \times 120 \mathrm{~mm}$ capillary column packed with MAGIC C18 (5 $\mu \mathrm{m}$ particle size, $20 \mathrm{~nm}$ pore size, Michrom Bioresources, Auburn, $\mathrm{CA})$ at a flow rate of $500 \mathrm{~nL} / \mathrm{min}$. Peptides were separated by a gradient of 5 to $35 \%$ acetonitrile/ $0.1 \%$ formic acid over $98 \mathrm{~min}, 40$ to $100 \%$ acetonitrile/0.1\% formic acid in $1 \mathrm{~min}$, and 100\% acetonitrile for $10 \mathrm{~min}$, followed by an immediate return to $2.5 \% \mathrm{CH}_{3} \mathrm{CN} / 0.1 \%$ formic acid, and a hold at $\mathrm{CH}_{3} \mathrm{CN} / 0.1 \%$ formic acid. Peptides were introduced into the linear ion trap via a nanospray ionization source and a laser pulled $\sim 3 \mu \mathrm{m}$ orifice with a spray voltage of $1.8 \mathrm{kV}$. Mass spectrometry data were acquired in a data-dependent "Top 10" acquisition mode, in which a survey scan from $\mathrm{m} / z 400$ to 1,600 is followed by 10 collision-induced dissociation MS/MS scans of the most abundant ions. Tandem mass spectrometry scans were acquired with the following parameters: isolation width: $2 \mathrm{~m} / z$, normalized collision energy: $35 \%$, activation Q: 0.250 and activation time $=30 \mathrm{~ms}$. Dynamic exclusion was enabled (repeat count: 2; repeat duration: 30 s; exclusion list size: 180 ; exclusion duration: $60 \mathrm{~s}$ ). The minimum threshold was 500. Product ion spectra were searched using the SEQUEST search engine on Proteome Discoverer 1.4 (Thermo Fisher Scientific) against a curated Bovine Uniprot [Bos taurus database (24,206 entries) downloaded July 9, 2014]. The 15 raw files from each sample (6 samples per period: 24 samples total) were searched as one contiguous input file and a single result file was generated for each sample. Search parameters were as follows: full trypsin enzymatic activity, 2 missed cleavages, and peptides between the molecular weight of 350 to 5,000; mass tolerance at $2 \mathrm{Da}$ for precursor ions, and 0.8 Da for fragment ions. Dynamic modifications on methionine $(+15.9949$ Da: oxidation; 4 maximum dynamic modifications allowed per peptide); and static modification on cysteine (+57.0215 Da: carbamidomethylation). The result files were then further analyzed by Scaffold 4.3 (Proteome Software, Portland, OR) to compare the unique peptide counts and to identify GO functions of the identified proteins. Cross-correlation significance and minimum peptide cutoff filters were applied to limit the false positive rates to less than $1 \%$ in the data sets.

\section{Statistical Analysis}

Statistical analysis of DMI, plasma parameters, milk composition, VFA, N balance, and high abundance protein data were performed using a linear mixed model for repeated measures ANOVA. The analyses were carried out with SAS software (version 9.4, SAS Institute Inc., Cary, NC). Preliminary data screening using PROC UNIVARIATE revealed that all dependent variables were approximately normally distributed. Data were analyzed by MIXED procedure of SAS with baseline values used as covariates and day as the repeated measure. All data are presented as least squares means \pm 
standard error of the mean and were considered to be significantly different at $P<0.05$. Trends were recognized at $P<0.10$.

Analysis of spectral abundance from the low abundance protein data was performed using a generalized linear mixed model. Data were analyzed by GLIMMIX procedure of SAS with baseline values used as covariates and day included as the repeated measure. A Poisson distribution was assumed because all dependent variables were count data. Low-abundance protein results were adjusted by the false discovery rate using the MULTTEST procedure of SAS. All data were presented as least squares means \pm standard error of the mean and were considered to be significantly different at $P<0.05$. Trends were recognized at $P<0.10$.

\section{RESULTS}

\section{Diet and DMI}

Total CP (\% of DM) was similar in both diets and a $13 \%$ difference (\% of $\mathrm{CP}$ ) in the RDP:RUP ratio between diets was achieved while maintaining similar $\mathrm{NDF}, \mathrm{NFC}$, and $\mathrm{NE}_{\mathrm{L}}$ content (\% of DM; Table 1). Dry matter intake was not different between the 2 treatment groups (Table 2).

\section{Milk Yield and General Composition}

Total milk yield as well as concentrations and yields of the individual milk constituents were not different between the 2 treatment groups (Table 2). Similarly, SCC was not significant between groups. The MUN was higher $(P=0.04)$ in milk samples analyzed from the RDP group $(15.7 \mathrm{mg} / \mathrm{dL})$ compared with those from the RUP group $(14.6 \mathrm{mg} / \mathrm{dL})$.

\section{Plasma Metabolites}

Plasma glucose, BHB, and fatty acid concentrations did not differ between treatment groups (Table 3 ). The PUN concentrations were higher $(P=0.01)$ from cows fed the RDP diet $(1.02 \mathrm{mmol} / \mathrm{L})$ compared with samples from cows fed the RUP diet $(0.98 \mathrm{mmol} / \mathrm{L})$. A significant period effect was observed on the concentrations of plasma BHB $(P \leq 0.01)$ and PUN $(P \leq 0.01)$.

\section{Rumen VFA}

Rumen propionate concentrations tended to be higher in cows that were fed the RUP diet $(P=0.06$; Table 4); however, this response was primarily due to an outlier measured in the second period. For the remaining discussion, this trend was not included in the data interpretation.

\section{N Partitioning}

Nitrogen balance data are presented in Table 5 as total $\mathrm{N}$ excreted as well as proportion of $\mathrm{N}$ intake. Nitrogen intake was similar between the RDP and RUP diets $(718$ and $717 \mathrm{~g} / \mathrm{d}$, respectively; $P=0.94)$. Total fecal, urine, and milk $\mathrm{N}$ output (g/d or $\mathrm{g} / \mathrm{g}$ of $\mathrm{N}$ intake) was not different between treatment groups. No effect of diet on calculated $\mathrm{N}$ retention was observed. Urine $\mathrm{N}$ excretion was affected by period.

\section{High Abundance Milk Proteins}

Concentrations of both $\kappa-\mathrm{CN}(P=0.04)$ and total casein $(P<0.01)$ was lower in milk samples from the RUP group (5.39 and $36.3 \mathrm{mg} / \mathrm{mL}$, respectively) compared with the RDP group (5.61 and $37.8 \mathrm{mg} /$ $\mathrm{mL}$, respectively). Total $\alpha-\mathrm{CN}(P=0.06)$ concentra-

Table 2. Daily DMI, milk yield, and milk components of Holstein dairy cattle fed diets with either a high $\mathrm{RDP}: \mathrm{RUP}$ ratio (RDP) or a low RDP:RUP ratio (RUP)

\begin{tabular}{|c|c|c|c|c|c|}
\hline \multirow[b]{2}{*}{ Item } & \multicolumn{2}{|c|}{ Treatment } & \multirow[b]{2}{*}{$\mathrm{SED}^{1}$} & \multicolumn{2}{|c|}{$P$-value } \\
\hline & $\mathrm{RDP}$ & RUP & & Treatment & Period \\
\hline DMI $(\mathrm{kg} / \mathrm{d})$ & 24.2 & 24.2 & 0.7 & 0.94 & 0.99 \\
\hline Milk yield (kg/d) & 58.3 & 58.7 & 3.5 & 0.87 & 0.05 \\
\hline \multicolumn{6}{|c|}{ Milk component yield $(\mathrm{kg} / \mathrm{d})$} \\
\hline Fat & 1.56 & 1.48 & 0.04 & 0.80 & 0.99 \\
\hline Protein & 1.71 & 1.72 & 0.07 & 0.83 & 0.25 \\
\hline \multicolumn{6}{|c|}{ Milk component (\%) } \\
\hline Fat & 3.48 & 3.43 & 0.22 & 0.80 & 0.99 \\
\hline Protein & 2.96 & 2.93 & 0.13 & 0.83 & 0.25 \\
\hline $\mathrm{SCC}(\times 1,000)$ & 55.5 & 78.2 & 23.7 & 0.33 & 0.17 \\
\hline MUN (mg/dL) & 15.7 & 14.6 & 0.86 & 0.04 & $<0.01$ \\
\hline
\end{tabular}

${ }^{1} \mathrm{SED}=$ standard error of the difference. 
Table 3. Plasma metabolites from Holstein dairy cattle fed diets with either a high RDP:RUP ratio (RDP) or low RDP:RUP ratio (RUP)

\begin{tabular}{|c|c|c|c|c|c|}
\hline \multirow[b]{2}{*}{ Item $(\mathrm{mmol} / \mathrm{L})$} & \multicolumn{2}{|c|}{ Treatment } & \multirow[b]{2}{*}{$\mathrm{SED}^{1}$} & \multicolumn{2}{|c|}{$P$-value } \\
\hline & RDP & RUP & & Treatment & Period \\
\hline Glucose & 3.51 & 3.52 & 0.04 & 0.77 & 0.68 \\
\hline BHB & 0.26 & 0.27 & 0.01 & 0.67 & $<0.01$ \\
\hline Plasma urea $\mathrm{N}$ & 1.02 & 0.98 & 0.01 & 0.01 & $<0.01$ \\
\hline Fatty acids & 0.10 & 0.09 & 0.01 & 0.66 & 0.96 \\
\hline
\end{tabular}

${ }^{1} \mathrm{SE}=$ standard error of the difference.

tion tended to be higher in milk samples collected from the RUP group $(16.3 \mathrm{mg} / \mathrm{mL})$ compared with the RDP group $(15.7 \mathrm{mg} / \mathrm{mL})$. A period effect was present on $\beta-\mathrm{CN}, \kappa-\mathrm{CN}$, and total casein concentrations. No difference was found between treatment groups in the skim milk whey fraction (Table 6).

\section{Low Abundance Milk Proteins}

Analysis of the skim milk samples from both dietary groups resulted in identification of 595 low abundance proteins (complete list in Supplemental File S1; https:/ / doi.org/10.3168/jds.2017-12647). Of these, 292 were present at high enough peptide counts to be compared statistically across treatments. Using a correction for multiple tests, no treatment, day, or treatment by day effects were observed to affect the protein count of any of the proteins (Table 7).

\section{DISCUSSION}

\section{Effect of Diet RDP:RUP Ratio on N Partitioning}

Isonitrogenous and isoenergetic diets were formulated and used in this experiment with a 13\% (\% of $\mathrm{CP})$ difference in the RDP:RUP ratio between the 2 diets. The lack of difference between DMI, rumen VFA concentration, and milk yield observed between the 2 treatment groups supports the suggestion that diets supplied similar nutrient profiles to the cows. The aim of providing a different RDP:RUP ratio to the cows was to create a divergence in how the protein was degraded and consequently how the $\mathrm{N}$ was absorbed and used by the animal. We hypothesized that by altering the proportion of RDP and RUP in the diet for a lactating dairy cow would alter $\mathrm{N}$ utilization patterns, ultimately leading to changes in milk protein secretion profiles. Though the diet CP inclusion in this experiment (approximately $18.5 \%$ of $\mathrm{DM}$ ) was relatively high for a lactating dairy cow by the NRC standards (NRC, 2001), lower MUN and PUN concentrations in milk and plasma samples collected from cows fed a diet higher in RUP compared with those that were fed the RDP diet highlights that the diet composition successfully altered the $\mathrm{N}$ utilization patterns between treatment groups and is in agreement with previous research (Brito and Broderick, 2007; Totty et al., 2013).

\section{Milk Proteins Affected by Diet RDP:RUP Ratio}

The significant increase in total casein concentrations measured from cows fed the RDP diet could be related to a more efficient $\mathrm{N}$ and energy capture by microbes with higher MCP synthesis and hindgut MCP utilization and uptake as a result. Increased energy and $\mathrm{N}$ availability to the cow would likely increase mammary protein synthesis capacity, which would also result in

Table 4. Rumen VFA from Holstein dairy cattle fed diets with either a high RDP:RUP ratio (RDP) or low RDP:RUP ratio (RUP)

\begin{tabular}{|c|c|c|c|c|c|}
\hline \multirow[b]{2}{*}{ Item } & \multicolumn{2}{|c|}{ Treatment } & \multirow[b]{2}{*}{$\mathrm{SED}^{1}$} & \multicolumn{2}{|c|}{$P$-value } \\
\hline & $\mathrm{RDP}$ & RUP & & Treatment & Period \\
\hline Acetate $(\mathrm{mmol} / \mathrm{L})$ & 19.9 & 21.9 & 0.86 & 0.60 & 0.13 \\
\hline Acetate ( $\%$ of total) & 59.3 & 65.4 & 5.10 & 0.89 & 0.55 \\
\hline Butyrate $(\mathrm{mmol} / \mathrm{L})$ & 3.34 & 3.91 & 0.24 & 0.64 & 0.27 \\
\hline Butyrate (\% of total) & 10.9 & 10.8 & 0.85 & 0.91 & 0.27 \\
\hline Propionate $(\mathrm{mmol} / \mathrm{L})$ & 6.96 & 8.05 & 0.45 & 0.06 & 0.39 \\
\hline Propionate ( $\%$ of total) & 19.7 & 18.1 & 3.50 & 0.63 & 0.64 \\
\hline Acetate:propionate ratio & 2.85 & 2.76 & 0.06 & 0.22 & 0.17 \\
\hline Total VFA $(\mathrm{mmol} / \mathrm{L})$ & 35.1 & 33.9 & 2.18 & 0.76 & 0.60 \\
\hline
\end{tabular}

${ }^{1} \mathrm{SE}=$ standard error of the difference. 
Table 5. Nitrogen partitioning in plasma, urine, feces, and milk from Holstein dairy cattle fed diets with either a high RDP:RUP ratio (RDP) or low RDP:RUP ratio (RUP)

\begin{tabular}{|c|c|c|c|c|c|}
\hline \multirow[b]{2}{*}{ Item } & \multicolumn{2}{|c|}{ Treatment } & \multirow[b]{2}{*}{$\mathrm{SED}^{1}$} & \multicolumn{2}{|c|}{$P$-value } \\
\hline & $\mathrm{RDP}$ & RUP & & Treatment & Period \\
\hline \multicolumn{6}{|l|}{$\mathrm{N}$ intake $(\mathrm{g} / \mathrm{d})$} \\
\hline Forage & 193 & 193 & 5.99 & 0.94 & 0.99 \\
\hline Concentrate & 524 & 523 & 16.2 & 0.94 & 0.99 \\
\hline Total & 718 & 717 & 22.2 & 0.94 & 0.99 \\
\hline \multicolumn{6}{|l|}{$\mathrm{N}$ output } \\
\hline Feces $(\mathrm{g} / \mathrm{d})$ & 196 & 210 & 10.4 & 0.26 & 0.77 \\
\hline Proportion of $\mathrm{N}$ intake & 0.27 & 0.28 & 0.009 & 0.38 & 0.56 \\
\hline Urine $(\mathrm{g} / \mathrm{d})$ & 253 & 237 & 9.31 & 0.23 & $<0.01$ \\
\hline Proportion of $\mathrm{N}$ intake & 0.35 & 0.32 & 0.01 & 0.14 & $<0.01$ \\
\hline $\operatorname{Milk}(\mathrm{g} / \mathrm{d})$ & 249 & 257 & 9.31 & 0.47 & 0.93 \\
\hline Proportion of $\mathrm{N}$ intake & 0.35 & 0.34 & 0.03 & 0.74 & 0.13 \\
\hline Retention $(\mathrm{g} / \mathrm{d})$ & 38.8 & 43.2 & 29.7 & 0.88 & 0.02 \\
\hline
\end{tabular}

${ }^{1} \mathrm{SE}=$ standard error of the difference.

a higher mammary casein synthesis rates. This would support our observation of increased milk total casein content from cows fed the RDP diet compared with those on the RUP diet.

Cows on the RUP diet also had lower individual $\beta-\mathrm{CN}$ and $\kappa-\mathrm{CN}$ concentrations in the skim milk fraction compared with those on the RDP diet. These results suggest that, at least in part, the results observed by Christian et al. (1999) and Li et al. (2015) are due to changes in ruminal protein availability and consequent animal $\mathrm{N}$ partitioning. The mechanisms of action could be due to specific AA availability to the mammary gland (MG), which is known to affect total protein secretion in the milk (DePeters and Cant, 1992; Rius et al., 2010). However, the diets used in the current study were predicted to satisfy all AA requirements, and without the observation of increased total milk protein output, it would indicate an additional requirement of specific AA above the current estimated AA requirements for synthesis of specific casein isoforms. Though this prospect is feasible, further investigation of mammary AA supply during differential RDP:RUP feeding with focus on its relationship to mammary function and casein isoform secretion is needed to address this mechanistic hypothesis. Hormone signaling, particularly that of insulin on the mTOR complexes, is another mechanism by which diet could affect mammary protein synthesis (Bionaz and Loor, 2011). Though the diets were designed to be isoenergetic and no significant changes in rumen VFA profile or plasma glucose concentration were observed, no plasma hormones were directly analyzed and therefore cannot be discounted to have played a role in the observed shift in casein due to diet.

Unfortunately, the current known functions of $\beta$-CN and $\kappa$-CN provide little aid in development of a secondary hypothesis as to why this differential regulation

Table 6. High abundance milk proteins from Holstein dairy cattle fed diets with either a high RDP:RUP ratio (RDP) or low RDP:RUP ratio (RUP)

\begin{tabular}{|c|c|c|c|c|c|}
\hline \multirow[b]{2}{*}{ Item } & \multicolumn{2}{|c|}{ Diet } & \multirow[b]{2}{*}{$\mathrm{SED}^{1}$} & \multicolumn{2}{|c|}{$P$-value } \\
\hline & $\mathrm{RDP}$ & RUP & & Treatment & Period \\
\hline \multicolumn{6}{|l|}{ Casein (mg/mL of skim milk) } \\
\hline$\beta-\mathrm{CN}$ & 16.3 & 15.8 & 0.29 & 0.06 & 0.03 \\
\hline$\kappa-\mathrm{CN}$ & 5.61 & 5.39 & 0.08 & 0.04 & 0.01 \\
\hline Total $\alpha-C N$ & 15.7 & 16.3 & 0.33 & 0.06 & 0.22 \\
\hline$\alpha_{S_{1}-C N}$ & 13.7 & 13.3 & 0.45 & 0.10 & 0.22 \\
\hline$\alpha_{\mathrm{S} 2}-\mathrm{CN}$ & 1.93 & 1.93 & 0.07 & 0.95 & 0.20 \\
\hline Total casein & 37.8 & 36.3 & 0.48 & $<0.01$ & 0.04 \\
\hline \multicolumn{6}{|l|}{ Whey (mg/mL of skim milk) } \\
\hline$\alpha-\mathrm{LA}$ & 1.48 & 1.50 & 0.09 & 0.66 & 0.26 \\
\hline$\beta-\mathrm{LGA}^{2}$ & 2.52 & 2.50 & 0.19 & 0.91 & 0.10 \\
\hline$\beta-\mathrm{LGB}^{3}$ & 1.60 & 1.64 & 0.11 & 0.72 & 0.52 \\
\hline Total $\alpha$-LA, $\beta$-LGA, $\beta$-LGB & 5.50 & 5.75 & 0.37 & 0.36 & 0.52 \\
\hline
\end{tabular}

${ }^{1} \mathrm{SE}=$ standard error of the difference.

${ }^{2} \beta$-LGA $=\beta$-lactoglobulin variant $\mathrm{A}$.

${ }^{3} \beta$-LGB $=\beta$-lactoglobulin variant $\mathrm{B}$. 
Table 7. Average peptide counts of low abundance milk proteins identified in samples from Holstein dairy cattle consuming either a high RDP:RUP ratio (RDP) or low RDP:RUP ratio (RUP) diet

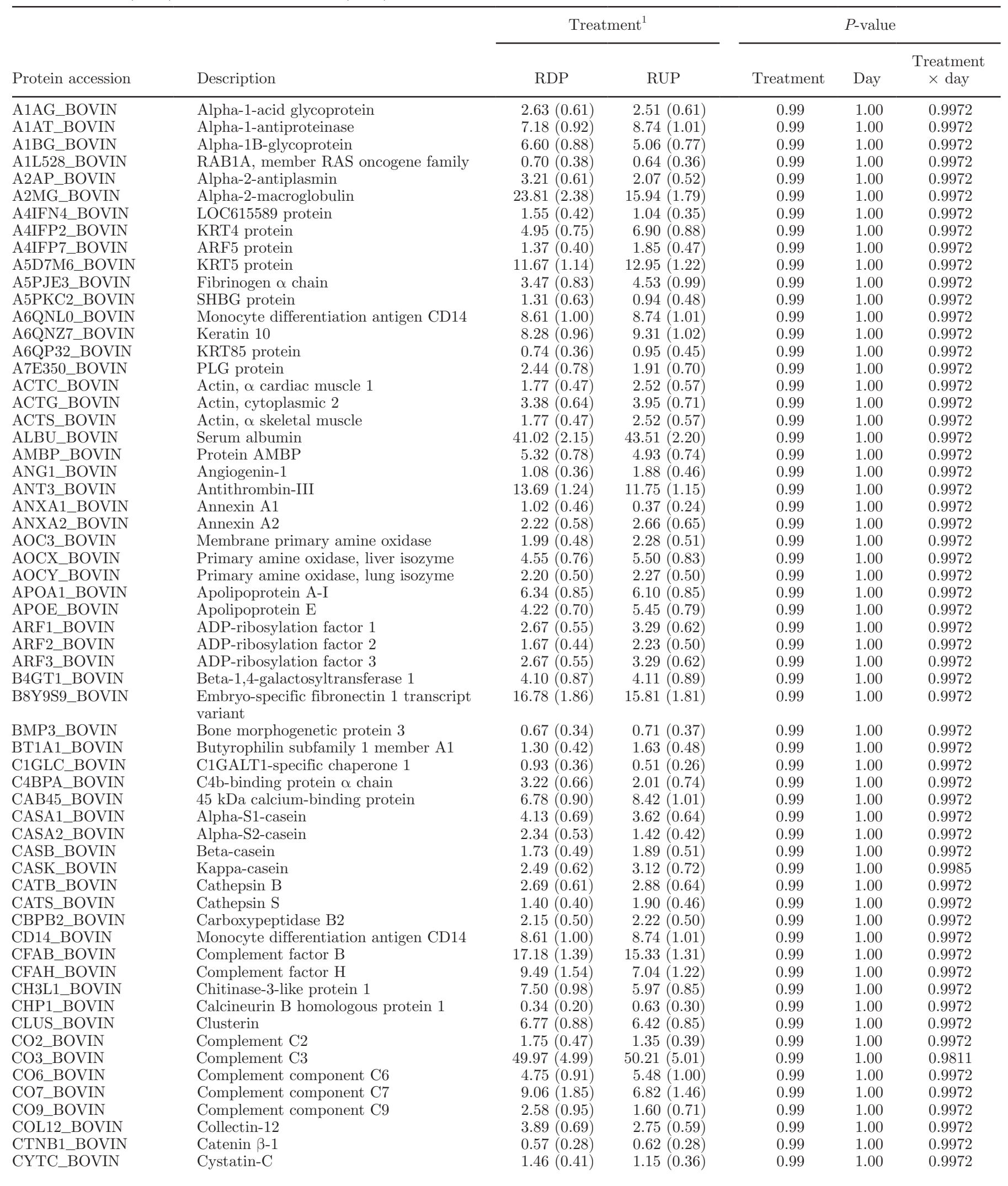


Table 7 (Continued). Average peptide counts of low abundance milk proteins identified in samples from Holstein dairy cattle consuming either a high RDP:RUP ratio (RDP) or low RDP:RUP ratio (RUP) diet

\begin{tabular}{|c|c|c|c|c|c|c|}
\hline Protein accession & Description & \multicolumn{2}{|c|}{ Treatment $^{1}$} & \multicolumn{3}{|c|}{$P$-value } \\
\hline E1B748_BOVIN & Hypoxia upregulated protein 1 isoform X1 & $0.96(0.62)$ & $2.25(1.24)$ & 0.99 & 1.00 & 0.9972 \\
\hline E1B991_BOVIN & keratin, type II cytoskeletal 2 epidermal & $3.76(0.65)$ & $4.22(0.69)$ & 0.99 & 1.00 & 0.9972 \\
\hline E1B9H5_BOVIN & $\begin{array}{l}\text { Transforming growth factor } \beta \text { receptor } \\
\text { type } 3 \text { isoform X2 }\end{array}$ & $2.87(0.59)$ & $1.86(0.50)$ & 0.99 & 1.00 & 0.9972 \\
\hline E1BA17_BOVIN & Collagen $\alpha-1$ (XIV) chain isoform X2 & $13.09(1.42)$ & $15.45(1.58)$ & 0.99 & 1.00 & 0.9972 \\
\hline E1BC58_BOVIN & Ras-related protein Rab-2B & $0.69(0.30)$ & $0.86(0.31)$ & 0.99 & 1.00 & 0.9972 \\
\hline E1BD43_BOVIN & Amine oxidase & $1.99(0.48)$ & $2.28(0.51)$ & 0.99 & 1.00 & 0.9972 \\
\hline E1BF27_BOVIN & $\begin{array}{l}\text { Putative sodium-coupled neutral amino } \\
\text { acid transporter } 10 \text { isoform X1 }\end{array}$ & $2.09(0.50)$ & $2.18(0.51)$ & 0.99 & 1.00 & 0.9972 \\
\hline E1BGW1_BOVIN & Mucin-15 & $0.41(0.26)$ & $0.36(0.24)$ & 0.99 & 1.00 & 0.9972 \\
\hline E1BGX8_BOVIN & HHIP-like 2 & $0.97(0.34)$ & $0.70(0.31)$ & 0.99 & 1.00 & 0.9972 \\
\hline E1BKT9_BOVIN & Desmoplakin & $5.96(1.17)$ & $7.22(1.35)$ & 0.99 & 1.00 & 0.9972 \\
\hline E1BLR9_BOVIN & Low quality protein: carboxypeptidase D & $2.82(0.57)$ & $2.74(0.57)$ & 0.99 & 1.00 & 0.9972 \\
\hline E1BMJ0_BOVIN & Factor XIIa inhibitor isoform X1 & $8.53(1.00)$ & $8.11(0.97)$ & 0.99 & 1.00 & 0.9972 \\
\hline E1BNY3_BOVIN & Semaphorin-6D precursor & $0.76(0.33)$ & $0.87(0.36)$ & 0.99 & 1.00 & 0.9972 \\
\hline ECHD1_BOVIN & Ethylmalonyl-CoA decarboxylase & $2.07(0.50)$ & $3.11(0.59)$ & 0.99 & 1.00 & 0.9972 \\
\hline ENOA_BOVIN & Alpha-enolase & $0.71(0.43)$ & $0.72(0.44)$ & 0.99 & 1.00 & 0.9972 \\
\hline ENPP3_BOVIN & $\begin{array}{l}\text { Ectonucleotide pyrophosphatase/ } \\
\text { phosphodiesterase family member } 3\end{array}$ & $2.51(0.77)$ & $1.64(0.58)$ & 0.99 & 1.00 & 0.9972 \\
\hline F12AI_BOVIN & Factor XIIa inhibitor & $8.34(1.01)$ & $7.97(0.98)$ & 0.99 & 1.00 & 0.9972 \\
\hline F1MAV0_BOVIN & Fibrinogen $\beta$ chain & $3.56(1.20)$ & $3.60(1.33)$ & 0.99 & 1.00 & 0.9972 \\
\hline F1MC11_BOVIN & Keratin, type I cytoskeletal 14 & $15.67(1.32)$ & $16.86(1.37)$ & 0.99 & 1.00 & 0.9972 \\
\hline F1MCF8_BOVIN & IGL@ protein & $4.10(0.68)$ & $4.11(0.68)$ & 0.99 & 1.00 & 0.9972 \\
\hline F1MD77_BOVIN & Laminin B2-like & $15.13(1.31)$ & $13.45(1.23)$ & 0.99 & 1.00 & 0.9972 \\
\hline F1MEA1_BOVIN & Transmembrane protein $132 \mathrm{~A}$ & $0.93(0.54)$ & $0.56(0.36)$ & 0.99 & 1.00 & 0.9972 \\
\hline F1MM86_BOVIN & Complement component $\mathrm{C} 6$ & $4.75(0.91)$ & $5.48(1.00)$ & 0.99 & 1.00 & 0.9972 \\
\hline F1MMD7_BOVIN & Inter- $\alpha$-trypsin inhibitor heavy chain $\mathrm{H} 4$ & $7.01(1.34)$ & $7.26(1.38)$ & 0.99 & 1.00 & 0.9811 \\
\hline F1MMK9_BOVIN & Protein AMBP & $5.32(0.78)$ & $4.93(0.74)$ & 0.99 & 1.00 & 0.9972 \\
\hline F1MMP5_BOVIN & Inter- $\alpha$-trypsin inhibitor heavy chain $\mathrm{H} 1$ & $7.05(1.36)$ & $6.62(1.29)$ & 0.99 & 1.00 & 0.9811 \\
\hline F1MNN7_BOVIN & Lipopolysaccharide-binding protein & $3.57(0.64)$ & $2.70(0.61)$ & 0.99 & 1.00 & 0.9972 \\
\hline F1MNT5_BOVIN & Mucin-20 & $1.58(0.45)$ & $1.58(0.41)$ & 0.99 & 1.00 & 0.9972 \\
\hline F1MNV5_BOVIN & Kininogen-1 & $9.34(1.04)$ & $8.70(1.00)$ & 0.99 & 1.00 & 0.9972 \\
\hline F1MNW4_BOVIN & Inter- $\alpha$-trypsin inhibitor heavy chain $\mathrm{H} 2$ & $9.72(1.42)$ & $8.29(1.26)$ & 0.99 & 1.00 & 0.9972 \\
\hline F1MPE1_BOVIN & CD109 antigen isoform X1 & $16.41(1.36)$ & $14.96(1.30)$ & 0.99 & 1.00 & 0.9972 \\
\hline F1MR22_BOVIN & $\begin{array}{l}\text { Polymeric immunoglobulin receptor } \\
\text { precursor }\end{array}$ & $19.64(1.50)$ & $19.72(1.49)$ & 0.99 & 1.00 & 0.9972 \\
\hline F1MRA6_BOVIN & Uncharacterized protein & $1.30(0.38)$ & $0.76(0.28)$ & 0.99 & 1.00 & 0.9972 \\
\hline F1MRD0_BOVIN & Actin, cytoplasmic 1 & $3.14(0.61)$ & $3.21(0.63)$ & 0.99 & 1.00 & 0.9972 \\
\hline F1MSZ6_BOVIN & Antithrombin-III & $14.04(1.26)$ & $12.34(1.18)$ & 0.99 & 1.00 & 0.9972 \\
\hline F1MTI7_BOVIN & Protein CutA & $0.38(0.22)$ & $0.61(0.27)$ & 0.99 & 1.00 & 0.9972 \\
\hline F1MU12_BOVIN & Keratin, type II cytoskeletal 8 & $1.54(0.42)$ & $1.59(0.43)$ & 0.99 & 1.00 & 0.9972 \\
\hline F1MU18_BOVIN & Oncostatin $\mathrm{M}$ receptor & $2.15(0.50)$ & $2.30(0.52)$ & 0.99 & 1.00 & 0.9972 \\
\hline F1MUT3_BOVIN & Xanthine dehydrogenase/oxidase & $25.81(2.62)$ & $26.82(2.69)$ & 0.99 & 1.00 & 0.9972 \\
\hline F1MUY2_BOVIN & $\begin{array}{l}\text { Keratin, type II cytoskeletal } 59 \mathrm{kDa} \text {, } \\
\text { component IV }\end{array}$ & $8.21(0.96)$ & $7.94(0.95)$ & 0.99 & 1.00 & 0.9972 \\
\hline F1MWN3_BOVIN & Nidogen-1 precursor & $0.40(0.25)$ & $0.62(0.31)$ & 0.99 & 1.00 & 0.9972 \\
\hline
\end{tabular}


Table 7 (Continued). Average peptide counts of low abundance milk proteins identified in samples from Holstein dairy cattle consuming either a high RDP:RUP ratio (RDP) or low RDP:RUP ratio (RUP) diet

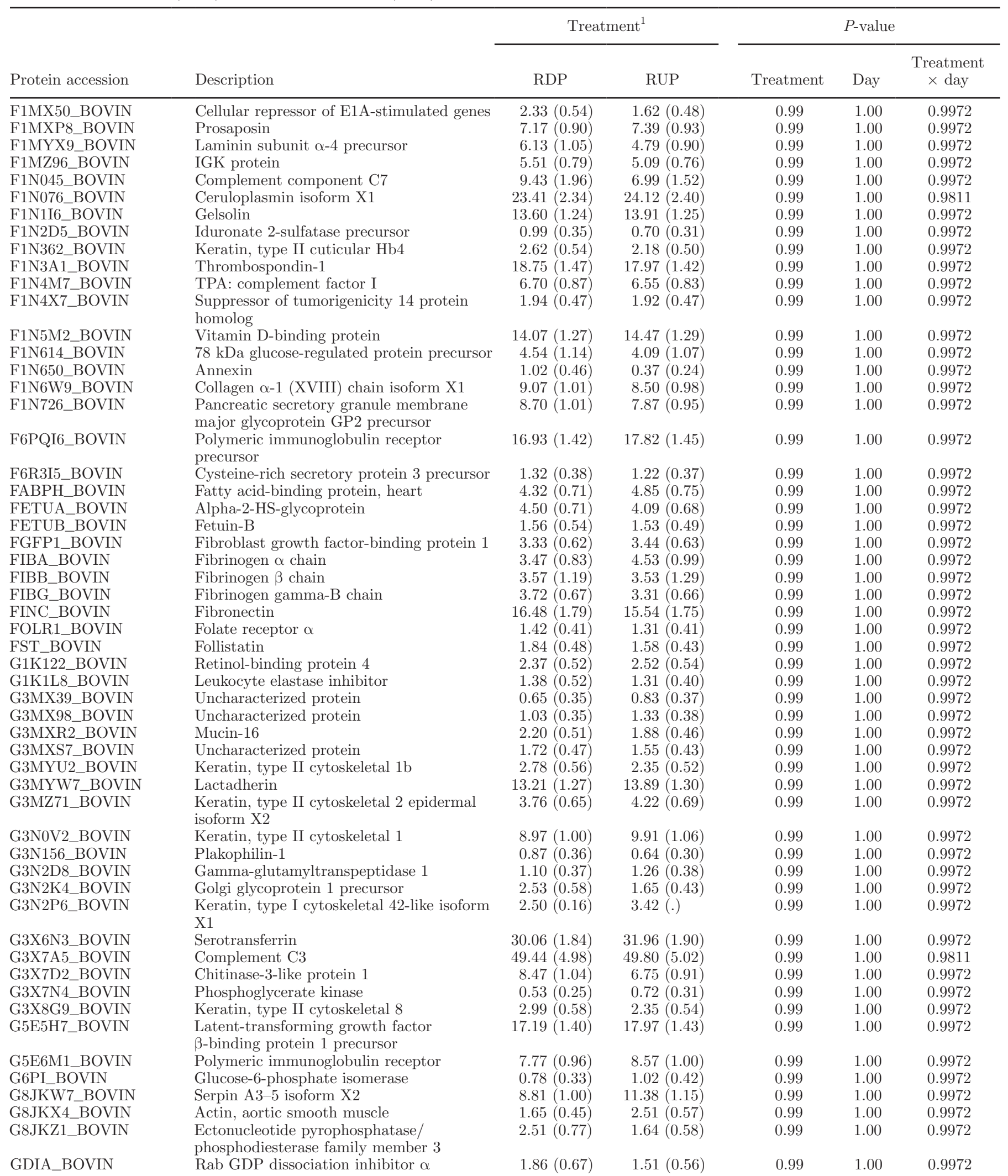


Table 7 (Continued). Average peptide counts of low abundance milk proteins identified in samples from Holstein dairy cattle consuming either a high RDP:RUP ratio (RDP) or low RDP:RUP ratio (RUP) diet

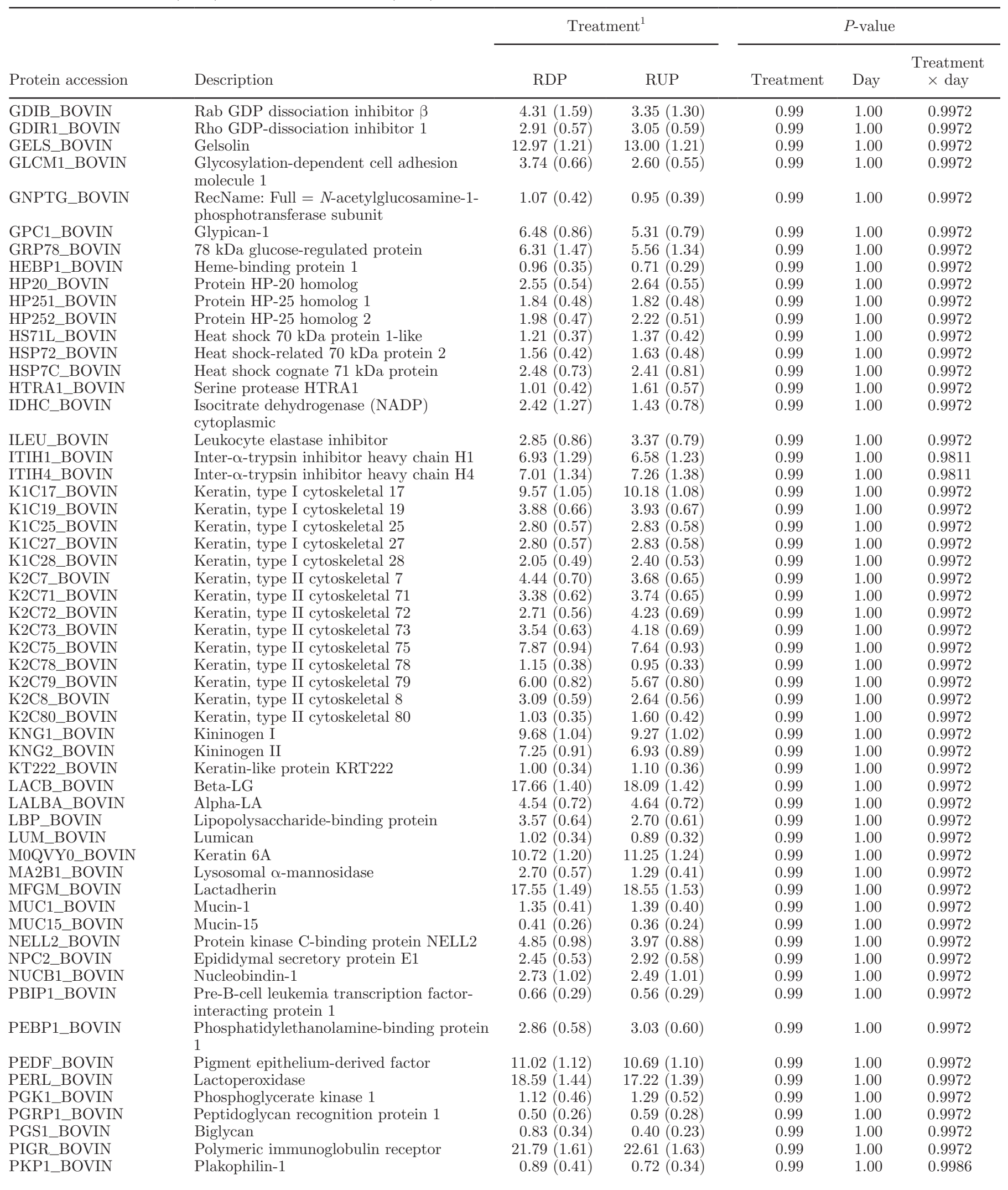


Table 7 (Continued). Average peptide counts of low abundance milk proteins identified in samples from Holstein dairy cattle consuming either a high RDP:RUP ratio (RDP) or low RDP:RUP ratio (RUP) diet

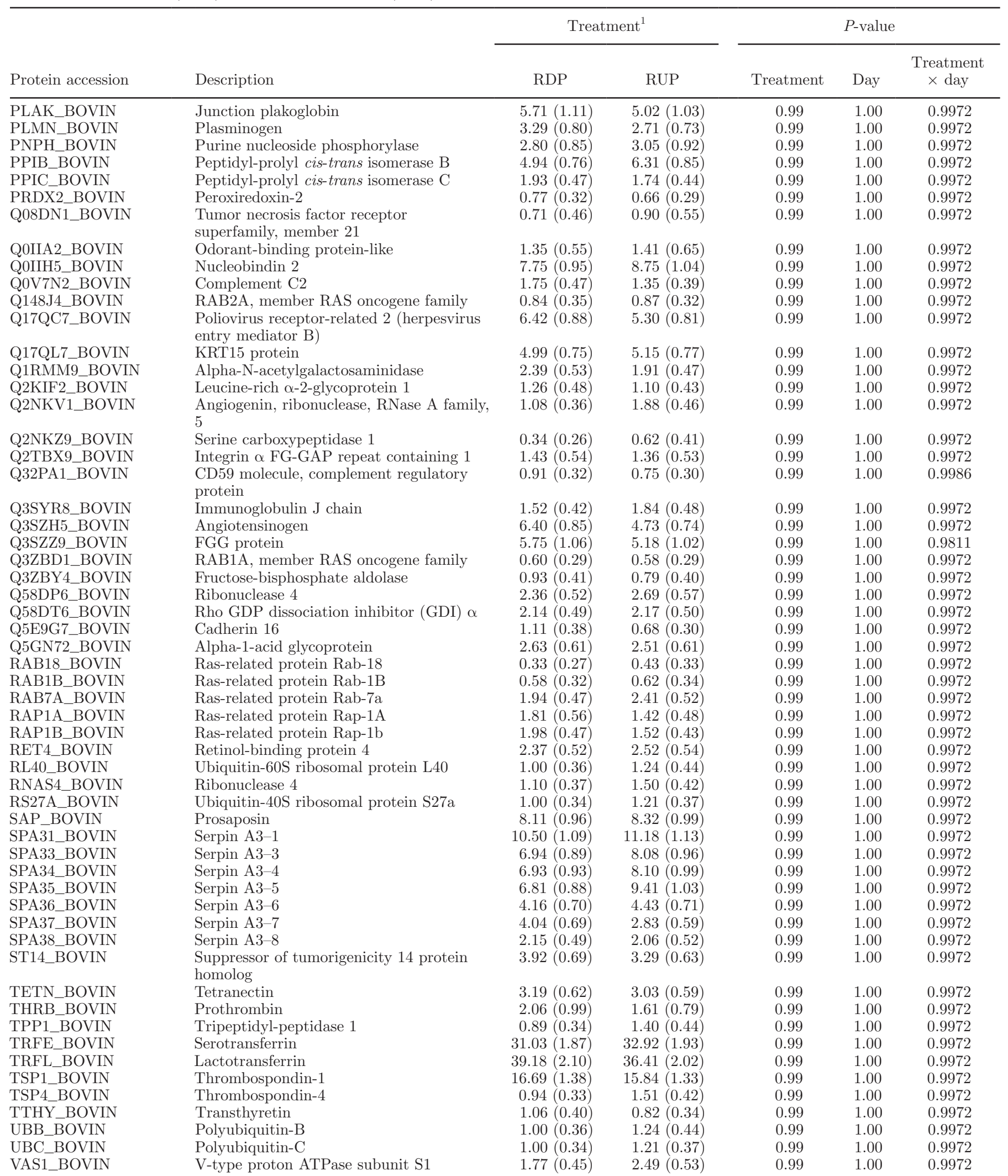


Table 7 (Continued). Average peptide counts of low abundance milk proteins identified in samples from Holstein dairy cattle consuming either a high RDP:RUP ratio (RDP) or low RDP:RUP ratio (RUP) diet

\begin{tabular}{|c|c|c|c|c|c|c|}
\hline \multirow[b]{2}{*}{ Protein accession } & \multirow[b]{2}{*}{ Description } & \multicolumn{2}{|c|}{ Treatment $^{1}$} & \multicolumn{3}{|c|}{$P$-value } \\
\hline & & $\mathrm{RDP}$ & RUP & Treatment & Day & $\begin{array}{l}\text { Treatment } \\
\times \text { day }\end{array}$ \\
\hline VNN1_BOVIN & Pantetheinase & $2.20(0.58)$ & $1.11(0.39)$ & 0.99 & 1.00 & 0.9972 \\
\hline VTDB_BOVIN & Vitamin D-binding protein & $12.67(1.22)$ & $12.91(1.23)$ & 0.99 & 1.00 & 0.9972 \\
\hline XDH_BOVIN & Xanthine dehydrogenase/oxidase & $25.45(2.42)$ & $26.53(2.50)$ & 0.99 & 1.00 & 0.9972 \\
\hline YKTE_BOVIN & Synaptobrevin homolog YKT6 & $1.01(0.33)$ & $0.89(0.37)$ & 0.99 & 1.00 & 0.9972 \\
\hline
\end{tabular}

${ }^{1}$ Standard error values are presented in parentheses adjacent to means.

might occur. The calcium-insensitive $\mathrm{\kappa}-\mathrm{CN}$ is known to play an important role in micelle stability (Shekar et al., 2006), whereas the function of $\beta-\mathrm{CN}$ is unclear. Through a lactation, $\beta$-CN knockout mice secrete less milk protein, despite maintaining a normal lactation. The lower milk protein due to $\beta$-CN knockout is partially compensated through increased secretion of other casein isoforms (Kumar et al., 1994), indicating no crucial role in protein function or secretion.

Over 590 low abundance proteins were identified using a combination of fractionation and enrichment techniques. Although no effect of dietary treatment on the low abundance protein profile was observed, the identified proteins are known to have a large breadth of functions and included known bioactive proteins such as lactadherin, lactoperoxidase, lactoferrin, and osteopontin. Gene ontological analysis revealed that $83 \%$ of the low abundance proteins with identified GO functions were involved in cellular processes such as protein folding and stabilization, signal transduction, cell adhesion, complement activation pathways, and glycolytic and catabolic processes. Additionally, 73\% of low abundance proteins identified with known GO functions involved in binding processes were predominately proteins involved in metal-ion binding such as calcium, copper, magnesium, manganese, and zinc as well as ATP and GTP binding. Twenty-five percent of the low abundance proteins identified with known GO functions were involved in immune system regulation and these proteins were involved in activation of the complement proteins, the innate immune response, and antibacterial activities. Many of the low abundance proteins have multifunctional properties contributing to the complex regulation of cellular metabolism.

In agreement with previous research, many of the low abundance proteins identified in the current study are characterized generally as common nonmammary specific cellular proteins and more research is needed in this field to understand the pathways that lead to presence of these proteins in milk, as well as the physi- ological and metabolic factors affecting milk protein expression within the MG.

\section{Effect of DIM on Milk Protein Profile}

Using a double-crossover design, otherwise known as a switchback design, also allowed for investigation into the effect of DIM on the milk protein profile. The concentrations of $\beta-\mathrm{CN}, \kappa-\mathrm{CN}$, and total milk casein increased with increasing DIM. These results are consistent with previous studies (see review by Barber et al., 2005) and may be due to increased synthesis of casein in response to the positive energy status, reduced mammary protease activity, hormonal control, or regulation by an advancing pregnancy rather than directly due to stage of lactation (Barber et al., 2005).

None of the identified low abundance proteins were influenced by DIM. This was not expected considering that the trial encompassed $63 \mathrm{~d}$ and many whole-animal metabolic and physiologic changes occur through the progression of lactation, including changes at the tissue level as the MG undergoes involution, and inflammation in the MG subsides (Zhang et al., 2015a,b). Two factors may play into this lack of day effect. First, the animals were in mid lactation, which encompasses a period of less drastic mammary- and whole-animal-level shifts: energy balance has positively stabilized, milk production has peaked, and many of the postpartum diseases have subsided. This stabilization of the milk proteome in the mid-lactation stage is supported by recent work outlined by Zhang et al. (2017), who reported stable percentages of low-abundance proteins involved in enzymatic activity, immunity, and transport functions throughout the mid-lactation period of dairy cattle. A second factor that could come into play is animal variation. Though the research described herein used a robust switchback design to address the stated hypothesis, individual animal variation in parameters such as lactation persistency, rates of alveolar senescence, and nutrient utilization efficiency could prevent a true 
portrait of the effect of time on the milk proteome, particularly that of the lower abundance milk proteins that are present at low concentrations.

\section{CONCLUSIONS}

Nutritional manipulation of the dairy cow's diet to alter milk composition offers a promising approach to naturally enhance the milk profile and could provide an opportunity for future development into functional foods directed toward increased healthfulness of milk. Although altering the RDP:RUP ratio of the diet did not induce any differences in the low abundance milk protein profile, the effect of this diet alteration on the casein profile produced by the cattle demonstrates the potential to influence specific mammary-derived milk proteins. Further investigation into the mechanisms of this interaction are needed to verify the outcomes observed in this smaller study and more accurately predict the effect of diet changes on the milk protein profile. Future studies could begin by gaining a deeper understanding on how the MG responds to changes in plasma AA composition along with examining the regulatory mechanisms behind AA transport across the mammary epithelia and how a change in AA availability to the MG influences protein synthetic pathways.

\section{ACKNOWLEDGMENTS}

This research was supported by the USDA-National Institute of Food and Agriculture Hatch Grant number VT-H02009. Equipment use included use of pieces funded by National Institutes of Health (NIH) Grant Numbers 5 P30 RR032135 from the Center of Biomedical Research Excellence (COBRE) Program of the National Center for Research Resources and 8 P30 GM 103498 from the National Institute of General Medical Sciences. The Vermont Genetics Network Proteomics Facility (University of Vermont, Burlington) is supported through NIH grant P20GM103449 from the INBRE Program of the National Institute of General Medical Sciences. Its contents are solely the responsibility of the authors and do not necessarily represent the official views of NIH. The authors thank the UVM Paul R. Miller Research and Educational Center staff, the undergraduate Cooperative for Real Education in Agricultural Management (CREAM) students, Elice Brooks, Nicole Gruszczynski, Taylor Hull, Elizabeth Kennett, Dana Ortiz, Adriana Wilford, and Sarah Zeger for their assistance in this work. The authors also thank Alan Howard (University of Vermont) for help with statistical analysis.

\section{REFERENCES}

Barber, D. G., A. V. Houlihan, F. C. Lynch, and D. P. Poppi. 2005. The influence of nutrition, genotype and stage of lactation on milk casein composition. Pages 203-216 in Indicators of Milk and Beef Quality. J. F. Hocquette and S. Gigli, ed. Wageningen Academic Publishers, Wageningen, the Netherlands.

Bionaz, M., and J. J. Loor. 2011. Gene networks driving bovine mammary protein synthesis during the lactation cycle. Bioinform. Biol. Insights 5:83-98.

Boehmer, J. L., J. L. Ward, R. R. Peters, K. J. Shefcheck, M. A. McFarland, and D. D. Bannerman. 2010b. Proteomic analysis of the temporal expression of bovine milk proteins during coliform mastitis and label-free relative quantification. J. Dairy Sci. 93:593-603.

Bordin, G. F. C. Raposo, B. de la Calle, and A. R. Rodriguez. 2001. Identification and quantification of major bovine milk proteins by liquid chromatography. J. Chromatogr. A 928:63-76. https://doi. org/10.1016/S0021-9673(01)01097-4.

Brito, A. F., and G. A. Broderick. 2007. Effects of different protein supplements on milk production and nutrient utilization in lactating dairy cows. J. Dairy Sci. 90:1816-1827.

Buccigrossi, V., G. de Marco, E. Bruzzese, L. Ombrato, I. Bracale, G. Polito, and A. Guarino. 2007. Lactoferrin induces concentrationdependent functional modulation of intestinal proliferation and differentiation. Pediatr. Res. 61:410-414.

Chatterton, D. E. W., D. N. Nguyen, S. B. Bering, and P. T. Sangild. 2013. Anti-inflammatory mechanisms of bioactive milk proteins in the intestine of newborns. Int. J. Biochem. Cell Biol. 45:1730-1747.

Christian, M. P., C. Grainger, B. J. Sutherland, B. J. Mayes, M. C. Hannah, and B. Kefford. 1999. Managing diet quality for cheddar cheese manufacturing milk. 2. Pasture v. grain supplements. J. Dairy Res. 66:357-363.

Dann, H. M., R. J. Grant, K. W. Cotanch, E. D. Thomas, C. S. Ballard, and R. Rice. 2008. Comparison of brown midrib sorghumsudangrass with corn silage on lactational performance and nutrient digestibility in Holstein dairy cows. J. Dairy Sci. 91:663-672.

DePeters, E. J., and J. P. Cant. 1992. Nutritional factors influencing the nitrogen composition of bovine milk: A review. J. Dairy Sci. 75:2043-2070.

Ghazalpour, A., B. Bennett, V. A. Petyuk, L. Orozco, R. Hagopian, I. N. Mungrue, C. R. Farber, J. Sinsheimer, H. M. Kang, N. Furlotte, C. C. Park, P.-Z. Wen, H. Brewer, K. Weitz, D. G. Camp, C. Pan, R. Yordanova, I. Neuhaus, C. Tilford, N. Siemers, P. Gargalovic, E. Eskin, T. Kirchgessner, D. J. Smith, R. D. Smith, and A. J. Lusis. 2011. Comparative analysis of proteome and transcriptome variation in mouse. PLoS Genet. 7:e1001393. https://doi org/10:1371/journal.pgen.1001393.

Hristov, A. N., R. P. Etter, J. K. Ropp, and K. L. Grandeen. 2004. Effect of dietary crude protein level and degradability on ruminal fermentation and nitrogen utilization in lactating dairy cows. J. Anim. Sci. 82:3219-3229.

Kennelly, J. J., J. A. Bell, F. Keating, and L. Doepel. 2005. Nutrition as a tool to alter milk composition. Adv. Dairy Tech. 17:255-275.

Korhonen, H., and A. Pihlanto. 2006. Bioactive peptides: Production and functionality. Int. Dairy J. 16:945-960.

Kumar, S., A. R. Clarke, M. L. Hooper, D. S. Horne, A. J. Law, J. Leaver, A. Springbett, E. Stevenson, and J. P. Simons. 1994 Milk composition and lactation of beta-casein-deficient mice. Proc. Natl. Acad. Sci. USA 91:6138-6142.

Li, S. S., J. S. Shen, D. X. Ren, and J. X. Liu. 2015. Effects of the processing methods of corn grain and soybean meal on milk protein expression profiles in dairy cows. Animal 9:267-274.

Lönnerdal, B., R. Jiang, and X. Du. 2011. Bovine lactoferrin can be taken up by the human intestinal lactoferrin receptor and exert bioactivities. J. Pediatr. Gastroenterol. Nutr. 53:606-614.

NRC. 2001. Nutrient Requirements of Dairy Cattle. 7th rev. ed. Natl. Acad. Press, Washington, DC.

Osorio, J. S., J. Lohakare, and M. Bionaz. 2016. Biosynthesis of milk fat, protein, and lactose: Roles of transciptional and posttran- 
scriptional regulation. Physiol. Genomics 48:231-256. https://doi. org/10.1152/physiolgenomics.00016.2015.

Park, Y. W., and M. S. Nam. 2015. Bioactive peptides in milk and dairy products: A review. Korean J. Food Sci. Anim. Resour. 35:831-840. https://doi.org/10.5851/kosfa.2015.35.6.831.

Raikos, V., and T. Dassios. 2014. Health-promoting properties of bioactive peptides derived from milk proteins in infant food: A review. Dairy Sci. Technol. 94:91-101.

Reynal, S. M., and G. A. Broderick. 2005. Effect of dietary level of rumen-degraded protein on production and nitrogen metabolism in lactating dairy cows. J. Dairy Sci. 88:4045-4064.

Rius, A. G., J. A. Appuhamy, J. Cyriac, D. Kirovski, O. Becvar, J. Escobar, M. L. McGilliard, B. J. Bequette, R. M. Akers, and M. D. Hanigan. 2010. Regulation of protein synthesis in mammary glands of lactating dairy cows by starch and amino acids. J. Dairy Sci. 93:3114-3127.

Sharma, S., R. S. Ingh, and S. Rana. 2011. Bioactive peptides: A review. Int. J. Bioautomation 15:223-250.

Shekar, P. C., S. Goel, S. D. Rani, D. P. Sarathi, J. L. Alex, S. Singh, and S. Kumar. 2006. Kappa-casein-deficient mice fail to lactate. Proc. Natl. Acad. Sci. USA 103:8000-8005.

Tacoma, R., J. Fields, D. B. Ebenstein, Y. W. Lam, and S. L. Greenwood. 2016. Characterization of the bovine milk proteome in early- lactation Holstein and Jersey breeds of dairy cows. J. Proteomics 130:200-210.

Totty, V. K., S. L. Greenwood, R. H. Bryant, and G. R. Edwards. 2013. Nitrogen partitioning and milk production of dairy cows grazing simple and diverse pastures. J. Dairy Sci. 96:141-149.

Tripathi, M. K. 2014. Effect of nutrition on production, composition, fatty acids and nutraceutical properties of milk. J. Adv. Dairy Res. 2:115. https://doi.org/10.4172/2329-888X.1000115.

Wang, X., X. Zhao, D. Huang, X. Pan, Y. Qi, Y. Yang, H. Zhao, and G. Cheng. 2017. Proteomic analysis and cross species comparison of casein fractions from the milk of dairy animals. Sci. Rep. 7:43020. https://doi.org/10.1038/srep43020.

Zhang, L., S. Boeren, J. A. Hageman, T. van Hooijdonk, J. Vervoort, and K. Hettinga. 2015a. Perspective on calf and mammary gland development through changes in the bovine milk proteome over a complete lactation. J. Dairy Sci. 98:5362-5373.

Zhang, L., S. Boeren, A. C. van Hooijdonk, J. M. Vervoort, and K. A. Hettinga. 2015b. A proteomic perspective on the changes in milk proteins due to high somatic cell count. J. Dairy Sci. 98:5339-5351.

Zhang, L., A. D. J. van Dijk, and K. Hettinga. 2017. An interactomics overview of the human and bovine milk proteome over lactation. Proteome Sci. 15:1. https://doi.org/10.1186/s12953-016-0110-0. 